\title{
Development of Trade Communication of Iran with Selected Countries
}

\section{Hamidreza Alipour}

Assistant Professor, Department of Management and Economics, Rasht Branch, Islamic Azad University

Rasht, Iran | Tel: +989111311776 | $\underline{\text { alipour@iaurasht.ac.ir }}$

\section{Leila Gholamipour}

PhD Student in Economics, Islamic Azad University

Kerman, Iran | gholamipour@ymail.com

Volume 6 No 2 (2016) ｜ＩSSN 2158-8708 (online) ｜ＤOI 10.5195/emaj.2016.105 | http://emaj.pitt.edu |

\begin{abstract}
The present study aimed to determine the trade potential of Iran with 13 countries that have made up the largest volume of foreign trade in the last decade. For this purpose, we have utilized the generalized gravity model and multivariate regression technique with panel data to estimate it. The results show that the most important variables affecting the trading volume of Iran are gross domestic product per capita and population, and that geographical distance variable had insignificant impact. On the other hand, the most trade gap of Iran is attributed to Turkey and the United Kingdom and the minimum gap is related to Afghanistan.
\end{abstract}

JEL-Classification: F15, E1, F1, C23

Keywords: economic integration, globalization, gravity model, panel data, trade gap.

\section{(cc) BY}

New articles in this journal are licensed under a Creative Commons Attribution 3.0 United States License.

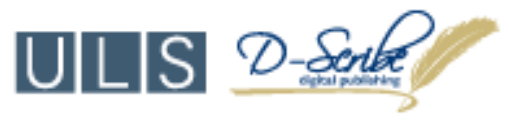

This journal is published by the University Library System of the University of Pittsburgh as part

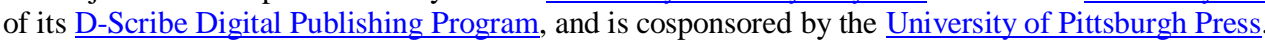




\section{Development of Trade Communication of Iran with Selected Countries}

\author{
Hamidreza Alipour \\ Leila Gholamipour
}

\section{Introduction}

Islamic Republic of Iran is unable to accept or reject globalization conditions at once. Therefore, in terms of various economic integrations it can realize the existing opportunities and clarify problems and challenges of globalization process. The main objective of this study was to ground a basis for Iran to enter into world trade. Therefore, considering the foreign trade process of Iran in recent years, first the countries with higher trade potential should be determined and then their trade potential should be estimated. Hence, trade gap of selected countries is estimated by utilizing the gravity model.

\section{Theoretical Basis}

Turning to regionalism and economic integrations are such solutions that developing economies adopt in order to cope and deal with globalization. Thereby they protect themselves from globalization problem and reach competitive advantage in the global market. In fact, understanding the national trade potential as a step towards global economy through removing tariff barriers can fulfill countries' access to wider markets, eliminate investment and technology transfer barriers, and as an opportunity can clarify ambiguous points of economic globalization. Developing countries are trying to resolve commercial and economic issues at a smaller scale in order to promote investment and economic growth (Tayebi and Azerbaijani, 2001). In a world where globalization has remarkable speed, regionalism is very important because inter-regional relationships can facilitate globalization. Regionalism take place in a structure based on positive peace and often starts from non-political processes and eventually leads to political and legal processes (Simbar, 2008). Moreover, it is possible to insure the economy during globalization process by gaining higher competitive power in the international trade aspect. In other words, attending trade arrangements and regional integration can provide the basics of attending global economy and encourages national economy towards interacting with global economy to seize the opportunities resulting from the impact of globalization process. It also keeps away the challenges and negative impacts of this process (Karimi, 2006).

\section{Literature}

Gravity model was first used by Tinbergen (1962) and Poyhonen (1963) in order to analyze mutual trade among European countries. However, the origin of the use of gravity models in social sciences fields and trends for fields such as astronomy, sociology and regional economy dates back to the 1930s.

Bendjilali (1997) examined the main factors in the relationships within OIC using gravity model and found out that trading volume is positively correlated with economic size of countries and negatively associated with transport cost as a barrier to distance variable. Al Atrash and Yousef (2000) using gravity model suggested that trading within the Arab world countries and trading of Arab world with other countries are less than that predicted by the gravity equation. The results indicate that, there is considerable scope for regional integration. Ghani (2007) has studied the effects of membership in OIC relative to trading volume. Using a standard gravity model, he stated that the OIC member countries are exposed to conflict and on average their institutional quality is lower than non-member countries. Meanwhile, Raimi and Mobolaji(2008) investigated the possibility of "faith-based integration" under the protective umbrella of the OIC. Their studies and the results are strong for increasing trade within the OIC. Ismail (2008) investigated Malaysian trade model with its 80 trading partners so that 20 countries are OIC members. The results showed that, Malaysia's trade is with countries that are similar in size but different in terms of interruption factor. Edmonds et al (2008) used the generalized gravity model to compare China's export prosperity with the East and Southeast Asian countries. The results indicate too much orientation of China to other countries. Ab Rahman and Abu-Hussin (2009) investigated Malaysia's trade relationships with the countries of the Persian Gulf Cooperation Council (GCC), which includes the United Arabic Emirates (UAE), Bahrain, Saudi Arabia, Oman, Qatar and Kuwait. Using trade intensity index, they demonstrated that Malaysian trade with each single GCC countries and GCC countries as a group of countries was very low during 1990-2007. Karagoz and OzanSaray (2010) detected factors affecting trade flows of Turkey with Guinea, Peru, Myanmar, Mexico, Laos, and Brunei. Coefficients from the fixed effect model show that trading volume between Turkey and the above mentioned countries is directly and positively influenced by the countries' economy, whereas distance has a negative role on trade relationships and population had no significant effect on trade volume. Abu-Hussin (2010) investigated trade relationships of Malaysia and Persian Gulf Cooperation Council (GCC) countries. Using a clear comparative advantage (RCA) trade intensity index, he suggested that trade relationship was negligible compared to the traditional trading partners. Nazia Gul 
and HafiizYasin (2011) have measured trade potential of Pakistan with 42 countries during 1981-2005. Finally, it turned out that Pakistan has the highest potential with the countries of Asia, Europe Union, Middle East, Latin America and North America. Evelyn et al found that based on the gravity model, culture and religion had no significant effect in enhancing mutual trade between Malaysia and the GCC countries. ZainalAbidin (2013) assessed the impact of economic factors on mutual exports between Malaysia and OIC member countries. Panel data model is used to estimate the gravity model and covers the period 1997 to 2009.Estimating the gravity model refers to the importance of economic size, degree of economic openness, inflation rate, and exchange rate, which are the factors affecting exports of Malaysia with OIC members. Estimating the effects of individual variables shows that distance and economic enterprises have significant influence on increased exports between Malaysia and OIC. Soori and Tashkini (2011) discussed factors affecting symmetric trade of Iran with countries of trade party in ASEAN, GCC, ECO and EU regional blocks. The results from estimating the model show that economic size, per capita income and distance are the most important variables that explain mutual trade of Iran and countries of trade party. Ashrafzadeh (2005) used the gravity model to study the economic integration among a group of Asian, European and African countries, included new variables such as the ratio of exports and imports in the gravity model, and refused the use of dummy variables and distance variable. The gravity model was specified based on Matyas technique (Matyas, 1997) and it was found that long-run tension of exports was greater than imports and in the long term after integration the trade balance will be positive. Tayebi and Azerbaijani (2003) used effective factors and studied both Iran and Ukraine. The results indicate that the studied variables not only have negative signs as expected, but also are not significant. In the other words, as a result of comparing the economic indicators of the two countries, their economic situation still makes integration between the two countries impossible. In addition, it affects on this claim.

\section{Results}

The following function shows the relationship between the trade potential of Iran and affecting factors. After estimation of model economic relationships, it is possible to identify and detect the effect of each factor. Since the purpose of this paper is to analyze the impact of these factors on increasing the national trading volume, it is necessary to calculate the tension of each of these variables. Thus, the most suitable form is Cobb-Douglas non-linear function.

$$
\begin{aligned}
& T R_{i j t} \\
& =\beta_{0} G D P I_{i t}^{\beta_{1}} G D P_{j t}^{\beta_{2}} D I S_{i j t}^{\beta_{3}} P O P I_{i t}^{\beta_{4}} P O P_{j t}^{\beta_{5}} L I N_{i j t}^{\beta_{6}} U_{i t}
\end{aligned}
$$

By finding the logarithm of the model, we turn it into a linear function. The final form of the model is thus as follows:

$$
\begin{aligned}
\operatorname{LogTR}_{\mathrm{ijt}}=\beta_{0} & +\beta_{1} \operatorname{LogGDPI}_{\mathrm{it}}+\beta_{2} \operatorname{LogGDP}_{\mathrm{jt}} \\
& +\beta_{3} \log \mathrm{DIS}_{\mathrm{ijt}}+\beta_{4} \operatorname{LogPOPI}_{\mathrm{it}} \\
& +\beta_{5} \operatorname{LogPOP} P_{j t}+\beta_{6} \operatorname{LogLIN}_{\mathrm{ijt}} \\
& +\mathrm{U}_{\mathrm{jt}}
\end{aligned}
$$

, where

TR: trading volume between Iran and selected business partners; GDP: gross domestic product per capita of selected countries; GDPI: Gross domestic product per capita of Iran; POP: population of selected countries; POPI: population of Iran; DIS: geographical distance of Iran with selected countries; LIN: Linder variable.

t: the time period from 2001 to 2011

$\mathrm{i}$ : Iran; $\mathrm{j}$ : the desired sections, including United Arabic Emirates, China, Republic of Korea, Turkey, Switzerland, Germany, India, Italy, France, Japan, Britain, Iraq and Afghanistan.

These countries were chosen because in the past 11 years, on average, had the highest volume of trade with Iran.

\section{a. Durability test}

One way to avoid spurious regression is to be ensured of stability of the data. Thus, before estimating the model, the statistical properties of panel data are examined in terms of durability or unit roots. For this purpose, unit root test, which is the most common test to recognize durability, is used. LLC test results for the variables of the model are presented in Table (1):

Table 1: LLC Test Results

\begin{tabular}{|c|c|c|}
\hline Variable & Test Statistic & P-Value \\
\hline LogTR $_{\text {it }}$ & -3.88 & 0.00 \\
\hline LogGDPI $_{\text {it }}$ & -9.84 & 0.00 \\
\hline LogGDP $_{j \mathrm{jt}}$ & -6.02 & 0.00 \\
\hline $\operatorname{LogPOPI}_{i t}$ & -30.28 & 0.00 \\
\hline $\operatorname{LogPOP}_{j t}$ & -12.24 & 0.00 \\
\hline $\operatorname{LogLIN}_{\mathrm{ijt}}$ & -2.89 & 0.00 \\
\hline
\end{tabular}

\section{b. Cointegration test}

The economic concept of cointegration is that, when two or more time series variables are related together based on theoretical basis, they form a long-term equilibrium relationship. Although it is possible for the time series to have random process (to be unstable), over time they follow each other well. According to Table 2 and both $\mathrm{ADF}$ and PP tests and their zero probability, the null hypothesis of non-cointegration between the variables of 
both panels is rejected. The results show that, variables in both panels form long-term equilibrium relationship.

Table 2: Pedroni cointegration test results

\begin{tabular}{|c|c|c|}
\hline $\begin{array}{c}\text { Test } \\
\text { Method }\end{array}$ & (P-Value), Test Statistic & Result \\
\hline $\begin{array}{c}\text { Group PP- } \\
\text { Statistic }\end{array}$ & $(0.00),-20.39$ & $\begin{array}{c}\text { Null } \\
\text { hypothesis is } \\
\text { rejected. }\end{array}$ \\
\hline $\begin{array}{c}\text { Group } \\
\text { ADF- } \\
\text { Statistic }\end{array}$ & $(0.00)-3.77$ & $\begin{array}{c}\text { Null } \\
\text { hypothesis is } \\
\text { rejected. }\end{array}$ \\
\hline
\end{tabular}

\section{c. Model estimation}

Now in order to determine the presence or absence of a separate intercept for each country, we first examine LM test and choose between combined data and noncointegrate data (fixed effects or random effects). In this study, pooled model is adopted. The results of estimating by pooled method are presented in Table (3):

Table 3: Estimation results

\begin{tabular}{|c|c|c|c|}
\hline \multirow{2}{*}{ Variable } & \multicolumn{3}{|c|}{ Pooled } \\
\cline { 2 - 4 } & Coefficient & T-Statistics & Prob \\
\hline LOG(GDP) & 0.54 & 5.16 & 0.00 \\
\hline DLOG(GDPI) & 0.56 & 2.11 & 0.03 \\
\hline LOGDIS & -0.0002 & -4.79 & 0.00 \\
\hline LOG( POP) & 0.42 & 4.63 & 0.00 \\
\hline LOG(POPI) & 0.51 & 3.63 & 0.00 \\
\hline LOGLIN & 0.01 & 2.00 & 0.04 \\
\hline$\overline{\mathrm{R}}^{2}=0.55$ & \multicolumn{3}{|c|}{$\mathrm{R}^{2}=0.57$} \\
\hline \multicolumn{4}{|c}{$D . W=1.35$} \\
\hline
\end{tabular}

As can be seen from the estimated output, all coefficient signs are consistent with economic theory and all coefficients are significant. The coefficient of determination obtained explains that variables are independent. This means that, around $60 \%$ of the changes in the trading volume of Iran with selected countries are explained by the independent variables. Meanwhile, there is no significant space between D-W statistics and 2. On the other hand, panel data and the short period of the study years have some limitations in terms of reliability of correlation.

\section{Discussion}

Gross domestic product per capita as economic size indicator of countries, play an important role in foreign trade and it is expected that, as it increases, national trade potential increases as well. The coefficient of this variable is equal to 0.54 . It means if GDP of partner countries increases by $1 \%$, trade potential of Iran will increase by more than $0.50 \%$. Asprob $=0$, it can be claimed to be significant. Another contributing factor to the trade potential of Iran is Iran's per capita gross domestic product with coefficient equal to 0.56 and has the most influence on foreign trade volume among the existing variables. Also, prob $<0.05$ indicates that the variable is significant. The third factor in this study is the geographical distance between the capital cities. It is expected that countries that are far from each other have less potential to increase trade due to reasons such as transportation cost, lack of cultural commonalities, and so on. The coefficient of this variable (0.0002) indicated a slight negative correlation between geographic distance and trade volume. Another factor examined in the present study is the population of Iran and the selected trade partners. As seen from Table 3, there is a positive and significant relationship between these variables and the volume of trade. Population tension of Iran and partner countries is 0.51 and 0.42 , respectively. That means if the population increases by $1 \%$, trade volume of the two countries will increase by about $0.50 \%$. Also, Linder variable is used as economic similarity index of countries and it is expected that the higher the Linder value is, the more the volume of trade between the two countries increases. The coefficient of this variable is equal to 0.01 , indicating a positive and significant relationship with the dependent variable.

\section{Conclusion}

Among the factors affecting the trade potential of countries, GDP of Iran and its trade partners has effective and similar contribution. After that the population of the countries has a positive effect on increasing the volume of trade between Iran and other countries, while economic similarity of countries has a far smaller contribution. Finally, geographical distance has the minimum influence that is very little and also negative. After estimating the parameters and determining the final form of the function, trade potential values of countries can be obtained by placing the actual values of the explanatory variables during the study years. Then, by comparing trade volume in recent years, the trade gap of Iran with 13 surveyed countries is determined. In order to compare the countries with each other, the mean trade gap is presented in Figure 1. As can be seen, the greatest trade gap of Iran is with Turkey and England, therefore there is a high potential to increase trade exchanges with these two countries, and the lowest trade gap is with Afghanistan. 


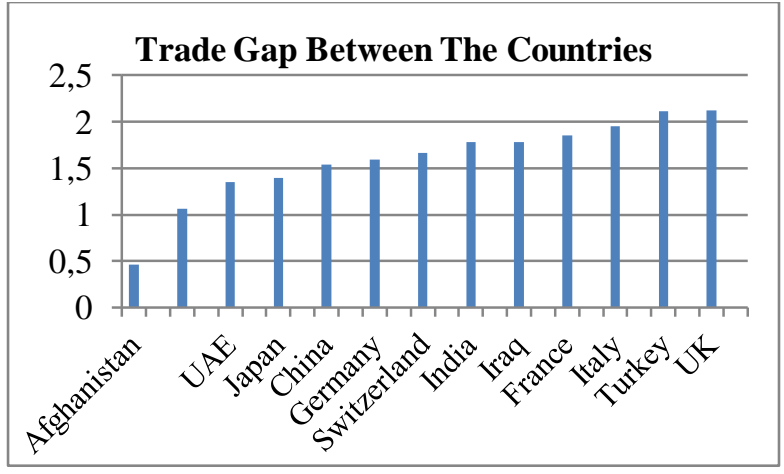

Fig.1. mean trade gap of Iran with selected countries

\section{REFERENCES}

Ashrafzade, Hamid Reza, 2005, The Economic Integration of Developing Countries; Application of Gravity Model with Fusion Data in GMM Method and Convergence, Journal of Commerce, No. 36, Pp 1-28.

Simbar, Reza, Iran and Regionalism in Southeast Asia: Strategies and Solutions in Iranian Foreign Policy, 2 Journals of Theoretical Politics, No. 5, Winter 1999 and Spring 2009.

Souri, Amir Reza, Shakini, Ahmad, 2011, Factors influencing mutual trade of Iran with regional blocks, Journal of Economic Modelling, Vol. III, No. 3.

Tayebi, Komeil, Azerbaijani, Karim, 2001, investigation of trade potential between Iran and Ukraine: using a gravity model, Journal of Commerce, No. 21.

Karimi, Hossein, 2006, globalization, economic integration and trade potential: investigation of gravity model in Iran trade analysis, Journal of Modern Economics and Business, No.5, p 118.

Abu-Hussin, M. F. (2010). Exploring International Trade between Malaysia and GCC Countries: Empirical Analysis on Trends.

Al Atrash, H., \& Yousef, T. (2000). Intra-Arab Trade: is it too Little?. IMF Working Paper, 00/10, International Monetary Fund (IMF).
Bendjilali, B. (1997). An intra-trade Econometric model for OIC member Countries: A Cross Country Analysis. IRTI Research Papers,No. 55.

Evelyn S., Ahmad, Z., \&Thirunaukarasu, S. (2011). Leveraging Trade Opportunities with Non-Traditional Partners: The Malaysia-GCC

Ghani, G. M. (2007). Does OIC Membership Reduce Trade? Journal of Economic Cooperation, 28(4): 39-62.

Gul, Nazia , Hafiz, M. Yasin,2011, The Trade Potential of Pakistan: An Application of the Gravity Model, The Lahore Journal of Economics,No 16 : 1: pp. 23-62

Hassan, M. K. (1998). An Empirical Investigation of Economic Cooperation Among the OIC Member Countries. Economic ResearchForum.

Karagoz, Kadir, OzanSaray,M. ,(2010), Trade Potential of Turkey with Asia-Pacific Countries: Evidence from Panel Gravity Model, International Economic Studies, Vol. 36, No. 1 (New Issue), pp. 19-26.

Ismail, N. (2008). Explaining Malaysian Bilateral Trade Using the Gravity Model. The Empirical Economic Letters, 7(8): 811-818.

Poyhonen, P. (1963). A Tentative Model for the Volume of Trade Between Countries. WelwirtschaftlichesArchiv, 90: 93-99.

Raimi, L. \&Mobolaji, H. I. (2008). Imperative of Economic Integration Among Muslim Countries: Lessons From EuropeanGlobalisation. Humanomics, 24 (2): 130-144

T inbergern, J. (1962). Shaping the World Economy: Suggestions for an International Economic Policy. Journal of Farm Economics,46(1): 271-283.

Zarzoso, M.I., \&Felicitas Nowak Lehmann., (2003). Augmented Gravity model: An Emprical Application to Mercosur European Union Trade Flows, Journal of Applied Economics, 5, 2, 219-316 